\title{
Do the Monetary Policy Makers Follow Rules? Testing Taylor's Rule for Nepal
}

\author{
Khagendra Katuwal ${ }^{1}$
}

\begin{abstract}
The study estimates Taylor's rule for Nepal by using the annual time series data for the period of 1988-2018. As a requirement of Taylor's rule, the output gap has been estimated by using Hodrick-Prescott filter. Consumer price index has been used as a measure of inflation and 91-days treasury bills rate is taken as the proxy for the short-term interest rate set by central bank of Nepal.The ordinary least square method has been used to estimate the Taylor's equation. As the Augumented Dickey-Fuller test shows that all the variables used in this study are in level form. The results show that there is a positive relationship of T-bills rate with inflation and output gap. Interest rate smoothing is found to be a major concern of central bank of Nepal but follows the Taylor's rule partially.
\end{abstract}

Key words: Taylor's rule, Output gap, Inflation gap, Interest rate, T-bills rate

\section{Introduction}

The debate on whether the monetary policy should be guided by some rules or be left under the discretion of the policy maker has the origin since the early days of the central banking but it has got heightened in the recent years especially after the financial crisis of 2007 (Taylor, 2011; Mishkin, 2018). The advocates of rules argue the monetary policy needs a law or rule to have precise prescription for setting policy instruments to deal with the economic circumstances. The policy rule restricts the discretionary options and increases the transparency, accountability and consistency in monetary policy decisions. For example, Friedman (1969) advocated a constant-money-growth rule in which money supply is set by the central bank to grow at a constant rate.

At the opposite pole of the rule, the advocates of discretion demand some flexibility in monetary policy making to deal with the day-to-day aspects of the economy with no prior public commitments about its objectives and actions. It is argued that rule based policy making does not give sufficient flexibility to deal with the uncertainty hovering around us which much pertinent issue in real economy(Mishkin, 2016). In the same line, it is also explained the role of judgment or discretion of the policymakers to contain such unforeseen contingencies at the time of policy making(Woodward, 2002; Svensson, 2005). For them,

1 Mr. Katuwal is an Assistant Professor and also a Ph.D. scholar at the Central Department of Economics, Tribhuvan University, Kirtipur, Email: ecokhagen@gmail.com 
discretion is a necessary evils in setting policy which the rule does not allow.

However, the rule based monetary policy making received more attention with the development of the new economic insights in the second half of the $20^{\text {th }}$ century such as the Lucas critique rational expectation and time inconsistency of policy (Doran\& Hickey,2009). Consequently, various forms of rules have been suggested, ranging from simple unconditional rules such as keeping the rate of money growth constant as of Friedman to more complicated conditional or feedback rules as of Taylor. The basic version of Taylor's rule states that the nominal interest rate set by the central bank is the weighted average of the output gap and inflation gap.If the inflation is above the target and economic growth is higher than potential, the central bank should increase the nominal interest to cool down the economy from the inflationary pressure (Taylor, 1993).

\section{Review of Literature}

Mehra and Minton (2007) tested Taylor's rule for the USA using the real time data by developing forward looking model. It is found that inflation and output gap well explain the interest rate determination in the USA. Farrell (2015) inferred the New Zealand, Canada and Australia in terms of policy preferences of Central Banks regarding inflation by using small Keynesian open economy model and Bayesian estimation. It is found that the monetary policy is optimal according to Taylor's rule and from the point of view of central banks. In the same line, Clarida, Gali \& Gertler (1998) estimated monetary policy reaction for countries such as the UK, Germany, Japan, USA, Italy and France by applying Generalized Method of Moments (GMM) method with reference to 1974-1994. It is found that the central banks of these aforesaid countries respond to expected inflation rather than lagged inflation, inflation rate is superior to exchange rate in fixing monetary policy and interest rate is much higher than that of other macroeconomic variables. Rzhevskyy and Papell (2012) estimated Taylor's rule for the monetary policy of USA with reference to 1966-1979. It is found that Taylor's rule is not being following by Fed and also monetary policy does not stabilize inflation rate. Kozicki (1999) focused on the monetary policy in the light of Taylor's rule and suggested that there is no robustness in rules to minor variations.Policy decisions made by policy makers are also limited; in special circumstances Taylor's rule has disadvantages in Kansas City, Missouri with reference to 1960-1997.

As of the case of developing countries, Sghaier (2013) estimated monetary policy of central bank of Turkey (CBT) by applying GMM method of estimation with reference to 1993-2011. It is found that CBT follows Taylor's rule and the primary objective of monetary policy is inflation. Asso, Kahn and Lesson (2010) applied Vector Autoregressive (VAR) model and found the optimization problem regarding adjusting policy rates at central banks by the policymakers and also suggested that Taylor rule must be incorporated with the macroeconomic models to forecast the economy. Moreira (2015) investigated monetary policy of Brazil and found that the monetary policy of Brazil is different from Taylor's rule by estimating OLS and GMM over the period of 2005-2013. It showed no robust effects of inflationary expectations and suggested to stabilize output against the stabilization of 
inflation. Pinga and Xiongb (2003) examined monetary policy of China by applying GMM estimation with reference to 1992-2001 and found that the monetary policy of China is unstable and suggested that China should implement interest rate reform to change the regime of monetary policy. Boamah (2012) used time series data of Ghana regarding inflation, GDP and output gap with reference to 1993-2011 by applying Hodrick-Prescott(HP) filtered test and Error Correction Model (ECM) test and found that as interest rate predictor, Taylor rule doesn't work in Ghana. Guney (2016) used Taylor's rule to investigate monetary policy rules of Turkey regarding inflation and output gap with reference to 2002-2014 by using GMM method, and found that Central Bank of Turkey (CBT) is concerned about price stability and responded to growth uncertainties and inflation.

There is no dearth of literatures on estimation of Taylor's rule but most of them are related to the developed countries such as the USA, the European Union, the United Kingdom, Japan among others (Woodford, 2001). Some of the literatures are also found in the case of developing countries (Guney, 2016). However, the literature on the Taylor's rule in Nepal rarely exists at least in the public domain. So, the study aims to fill this gap by testing the Taylor's rule in linear version for Nepal using annual time series data and examine whether it can explain monetary policy making by Nepal Rastra Bank (NRB) ${ }^{2}$.

\section{Methods and Data}

As discussed in the previous parts, this study is interested to examine whether NRB follows some rule in monetary policy making or not. For this the Taylor's rule for Nepal is estimated using annual data for the period of 1988-2018. Following Taylor (1993), the basic form of the rule to be used in monetary policy making can be written as -

$$
i_{t}=r^{*}+\pi_{t}+\alpha y_{t}+\beta\left(\pi_{t}-\pi^{*}\right)
$$

This rule shows that when central bank sets its policy instrument which is short term interest rate $\left(\pi_{t}\right)$, it should consider the long run equilibrium real interest rate $\left(\mathrm{r}^{*}\right)$, annual inflation rate $\left(\pi_{t}\right)$, output gap $\left(y_{t}\right)$ inflation gap $\left(\pi_{t}-\pi^{*}\right)$ where, $\pi^{*}$ is the longrun inflation targeted rate. The parameters $\alpha$ and $\beta$ are the adjustment coefficients. The output gap is the difference betweenactual and potential output that is calculated as $\frac{\boldsymbol{Y}_{\text {actual }}-\boldsymbol{Y}_{\text {potential }}}{\boldsymbol{Y}_{\text {potential }}} * 100$. Taylor (1993) considered $\mathrm{r}^{*}$ and $\pi^{*}$ to be 2 percent and $\alpha$ and $\beta$ to be 0.5 each.

For the purpose of empirical estimation of the Taylor's rule, the information on actual output is available while potential output may not be readily available which can be estimated using any standard technique. The information on actual inflation is easily available but the information on $\mathrm{r}^{*}$ and $\pi^{*}$ may not be readily available in public making empirical estimation of Taylor's rule difficult. In this case, the given equation (1) can be converted to estimable form as -

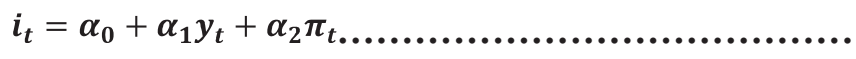

2 Nepal Rastra Bank is the Central Bank of Nepal. 
Where $\alpha_{0}=r^{*}-\beta \pi^{*}, \alpha_{1}=\alpha$ and $\alpha_{2}=1+\beta$

If the central bank is strictly following the Taylor's rule, then the parameters would be $\alpha_{1}=0.5$, and $\alpha_{2}=1.5$. However, this may not be the case everywhere then the parameters must be such that $\alpha_{1}>0$ and $\alpha_{2} \geq 1$,otherwise, the system would be unstable (Taylor, 199; Woodford, 2001). If $\alpha_{0}<0$, then, either the long run real interest rate is negative or targeted inflation is too high.

This study uses equation (2) for the Taylor's rule estimation in Nepal. There are various types of short term interest rate but this study uses the weighted average of the interest rate from 91 days T-bills as the short term interest rate or monetary policy instruments $\left({ }_{t}\right.$ ) because, it is the longest annual uninterrupted series available since 1989. For inflation rate, CPI has been used and both T-bills rate and inflation rate are taken from the Quarterly Economic Bulletin published by NRB. The information on real GDP has been collected from the various issues of the Economic Surveys published by Ministry of Finance (MoF). In order to find the output gap, Hodrick-Prescott (HP) filter has been used which is the most commonly used statistical method because of its flexibility in tracking the fluctuations of trend output (Konuki, 2010). The HP filter minimizes the sum of the square of the gap between the actual and potential output over the sample period subject to variation of potential output. It can be written as -

$$
\operatorname{Min} \sum_{t=1}^{T}\left(Y_{t}-Y_{t}^{p}\right)^{2}+\lambda \sum_{t=1}^{T}\left\lfloor\left(Y_{t+1}-Y_{t}^{p}\right)-\left(Y_{t}-Y_{t-1}^{p}\right\rfloor^{2}\right.
$$

Here, $Y_{t}$ and $Y^{p}$ are actual and potential outputs respectively. ' $\mathrm{t}$ ' is the sample period and $\lambda$ is the restriction parameter that captures degree of smoothness of the trend. The choice of the value of $\lambda$ determines how the fluctuation disappears and the actual output coincides to potential. As the data used for estimation are annual, following Raven and Uhlig (2002) this study has used $\lambda=6.25$.

To detect whether the series has unit root or not, Augumented Dickey-Fuller (ADF) test has been applied which shows that all the variables $i_{t}, y_{t}$ and $\pi_{t}$ are stationary in level form. Then, OLS method is used to estimate Taylor's rule for Nepal as stated in equation (2). The estimated OLS results were tested for the serial autocorrelation which is one of the common issues in time series data. Both Darwin-Watson (D-W) and Lagrangean Multiplier (LM) test show the presence of autocorrelation. Then, it isconsidered that the current policy rate or short term interest rate is also affected by the previous period's rate which is also found to be stationary in level form. This variable is also included in our model as -

$$
i_{t}=\alpha_{0}+\alpha_{1} y_{t}+\alpha_{2} \pi_{t}+i_{t-1 . \ldots \ldots \ldots \ldots \ldots . . . . .(3)}
$$

Finally, the equation (3) is estimated using OLS. The diagnostic test for autocorrelation has showed the absence of this issue in the results. 
38 | The Economic Journal of Nepal (Issue No. 151)

\section{Findings and Analysis}

The main focus of this study is to examine whether NRB responds to inflation and output gap through policy instrument using the linear version of Taylor's rule. The weighted average of 91 days T-bills rate has been considered as the short-term interest rate, a policy instrument, for the purpose of the study. So, as a part of the descriptive analysis, the trend of T-bills rate, inflation and output gap has been analyzed.

Over the study period (1988-2018), both T-bills rate and inflation have some erratic behavior. The inflation rate was more than 20 percent in 1991 which is the highest ever experienced inflation during the study period while it was lowest around 2 percent in 2000. Similarly, T-bills rate is also fluctuating over the period but less volatile than inflation. Interestingly, the pattern of their movement is more or less similar as shown in given figure 1.

Figure 1: T-bills Rate and Inflation

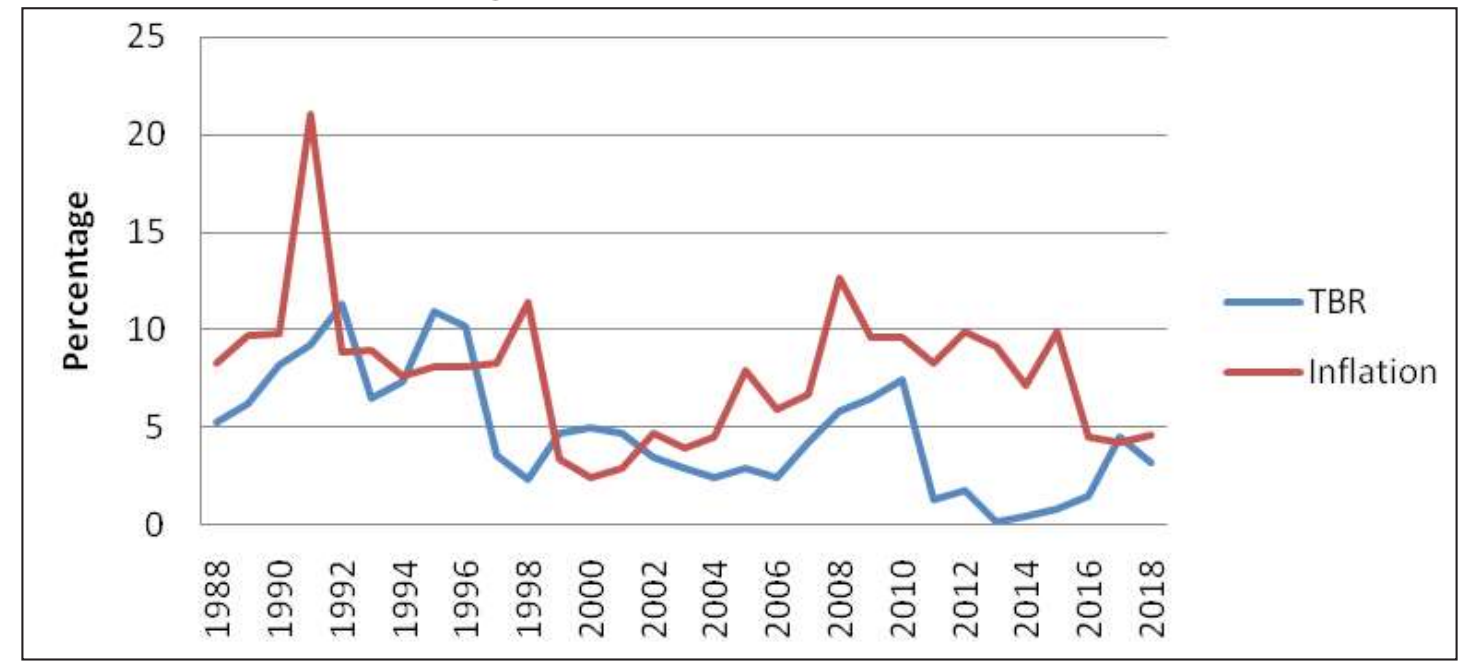

Source: NRB, 2019.

The cyclical behavior in real economic activities is shown by the fluctuating trend of the output gap in figure 2. It well presents that Nepal has most often experienced recessionary pressure as indicated by the negative values of the output gap and the longer was from 2001 to 2007 due to severity of armed conflict during this period. But as per expectation, T-bills rate has also similar trend implying some response by NRB to address the recessionary pressure in the economy. 
Figure 2: T-bills Rate and Inflation and Output Gap

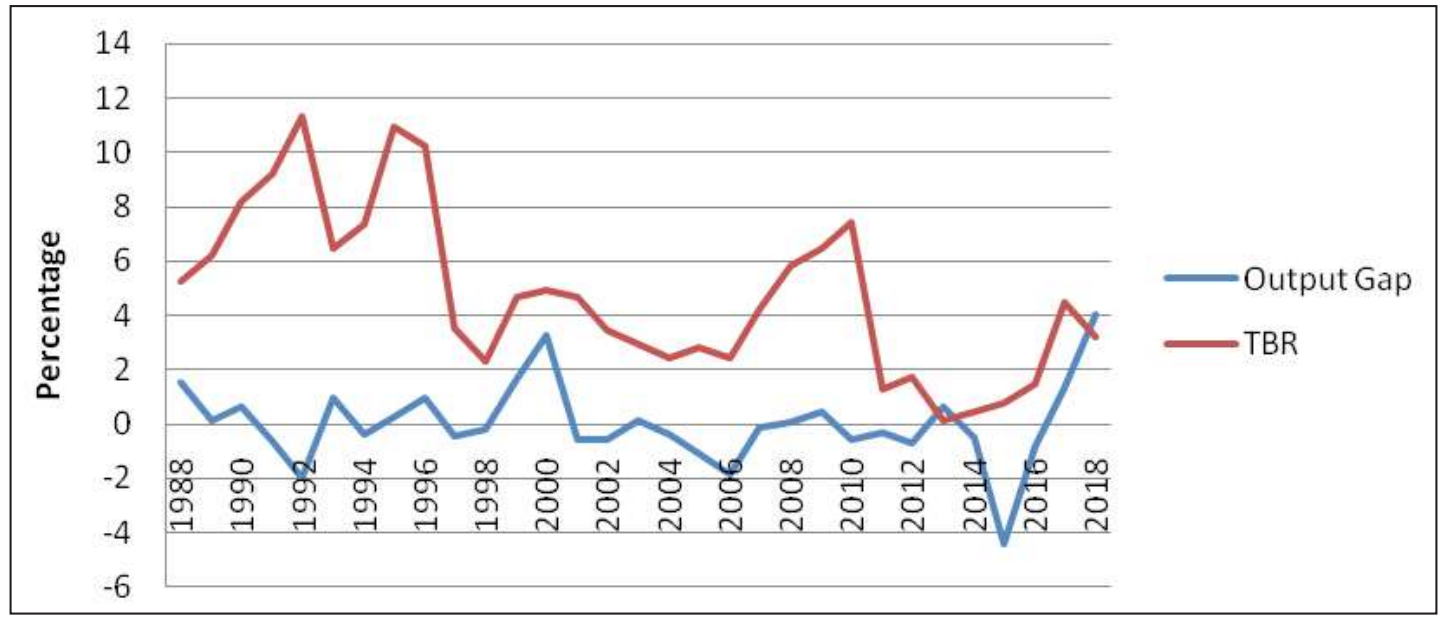

Source: NRB, 2019.

The figure indicates that NRB has tried to response the inflation and output gap similar to the Taylor's rule where T-bills rate is high when there is higher positive output gap and higher inflation rate. Similarly, T-bills rate is low during the period when inflation rate is low and output gap is negative. This implies NRB has tried to stabilize the economy through the policy instruments.

\section{Empirical Results and Discussions}

As discussed in the data and research methods section, this study has used the ADF test to detect the unit root of the series used in the study and the result of the test is presented in table 1 .

Table 1: ADF Test Results

\begin{tabular}{|l|l|l|c|}
\hline \multicolumn{1}{|c|}{ Variables } & t-Statistic & Prob. & Order of Integration \\
\hline TBR $(i)$ & -3.633609 & 0.0449 & $\mathrm{I}(0)$ \\
\hline Output Gap $(\mathrm{y})$ & -4.385253 & 0.0018 & $\mathrm{I}(0)$ \\
\hline Inflation $(\pi)$ & -3.245569 & 0.0307 & $\mathrm{I}(0)$ \\
\hline LTBR-1 & -3.745626 & 0.0362 & $\mathrm{I}(0)$ \\
\hline
\end{tabular}

Source: Author's calculation.

The output gap is stationary in level form at less than 1 percent level of significance where TBR, inflation and one period lag of TBR are stationary at level form with less than 5 percent significant level. Since all the variables used in the study are stationary in level form, the standard OLS method has been to estimate equation 2 and 3. 
40 | The Economic Journal of Nepal (Issue No. 151)

Table 2: OLS Estimates of Equation 2

\begin{tabular}{|l|c|c|c|c|}
\hline \multicolumn{1}{|c|}{ Variables } & Coefficients & Std. Error & t-Statistic & Prob. \\
\hline $\mathrm{C}$ & 2.214410 & 1.328949 & 1.666286 & 0.1072 \\
\hline $\operatorname{GAP}\left(\alpha_{1}\right)$ & 0.732625 & 0.418190 & 1.751895 & 0.0911 \\
\hline $\operatorname{INF}\left(\alpha_{2}\right)$ & 0.335797 & 0.155143 & 2.164440 & 0.0394 \\
\hline
\end{tabular}

Source: Author's calculation.

The OLS results from equation (2) showsthat the results are matched with the expectation of Taylor's rule where the positive coefficients of GAP and INF indicate that NRB increases short-term interest rate (T-Bills Rate) if actual GDP is greater than potential GDP and inflationary pressure rises. The coefficient of INF is statistically significant at 5 percent while GAP is significant at 10 percent. The results indicate that if output gap increase by 1 percent, then T-bills rate is increased by 0.7 percent while T-bills rate increases by 0.3 percent for an increase in inflation by 1 percent. This shows some responses of NRB to inflation and output gap but it does not strictly follow the Taylor's rule where the parameters would be $\alpha_{1}=0.5$ and $\alpha_{2}=1.5$ (Taylor, 199; Woodford, 2001).

Table 3: OLS Estimates of Equation 3

\begin{tabular}{|l|c|c|c|c|}
\hline \multicolumn{1}{|c|}{ Variables } & Coefficients & Std. Error & t-Statistic & Prob. \\
\hline C & 0.741014 & 1.096041 & 0.676082 & 0.5052 \\
\hline GAP & 0.312911 & 0.354096 & 0.883688 & 0.3853 \\
\hline INF & 0.123030 & 0.131927 & 0.932559 & 0.3600 \\
\hline LTBR & 0.648696 & 0.149711 & 4.332978 & 0.0002 \\
\hline
\end{tabular}

Source: Author's calculation.

In order to assess whether NRB cares the previous period of interest rate or not, this study has estimated equation (3) by including a period lagged value of T-bills rate, inflation and output gap. The OLS results show that the coefficients of GAP, INF and LTBR all have positive sign as per expectation but GAP and INF are now no more statistically significant but LTBR is highly significant at 1 percent. The significance of the lagged interest rate and insignificance of both inflation and the output gap suggests that NRB is focused to smoothinterest rates where if the previous period of interest rate was 1 percent higher, then this period the interest rate would be higher by 0.65 percent.

\section{Conclusion}

In Nepal,interest rate setting by NRB is not purely discretionary. The policy maker considers macro variables such as inflation and output gap. If the output gap i.e. difference between actual and potential GDP increases, NRB responds to this by increasing the nominal interest rate. Similarly, if the inflation increases, NRB increase the interest rate to contain 
inflation within the target. The responses of NRB are in line with the Taylor's rule but NRB does not follow this rule strictly in order to deal with the day to day economic circumstances. Apart from this, NRB considers interest rate smoothing based on interest rate of the previous period. If the rate ofprevious period is higher, it gives upward pressure to the current interest rate in Nepal.

\section{References}

Asso, P.F., Kahn, G.A. \& Lesson, R. (2010).The Taylor rule and the practice of central banking. Research Working Papers, The Federal Reserve Bank of Kansas City, Economic Research Department, , RWP No 10-05, 1-52.

Barro, R. J., \& Gordon, D. B. (1983).Rules, discretion and reputation in a model of monetary policy.Journal of Monetary Economics, 12(1), 101-121.

Baxter, M. and King,R. G. (1999). Measuring business cycles: Approximate band-pass filters for economic time series. The Review of Economics and Statistics, 81(4): 575-593.

Bernanke, B. S., \&Mishkin, F. S. (1997). Inflation targeting: A new framework for monetary policy. Journal of Economic Perspectives, 11(2), 97-116.

Boamah, M.I. (2012). Taylor rule and monetary policy in Ghana.International Journal of Economics and Finance, 4(7), 15-21.

Calvo, G. A. (1978). On the time-inconsistency of optimal policy in a monetary economy. Econometrica, 46(6), 1411-1428.

Clarida, R., Gali, J. \&Gertler, M. (1998). Monetary policy rules in practice: Some international evidence. European Economic Review, 42, 1033-1067.

Doran, D.\& Hickey, R. (2009).A discussion of the Taylor rule. Quarterly Bulletin (Central bank\&financial services authority of Ireland, CBFSAI), 3, 81-93.

Farrell, J.P. (2015). Taylor rules, central bank preferences and inflation targeting. Sheffield Economic Research Paper Series, SERPS no. 2015023, 1-27.

Friedman, M.\& Schwartz, A. (1963).A monetary history of the United States, 1867-1960. Princeton, NJ: Princeton University Press.

Friedman, M.(1969).The optimum quantity of money. In: Friedman, M., The Optimum Quantity of Money and Other Essays. Aldine Publishing Company, Chicago.

Guney, P.O. (2016). Does the central bank respond to output and inflation uncertainties in Turkey. Central Bank Review, 16(2), 53-57.

Konuki, T. (2010). Estimating potential output and the output gap in Slovakia. Eastern European Economics, 48(2), 39-55.

Kozicki, S. (1999). How useful are Taylor rules for monetary policy? Federal Reserve Bank of Kansas City, Economic Review, Second Quarter, 5-33. 
42 | The Economic Journal of Nepal (Issue No. 151)

Mehra, Y.P. \& Minton, B.D. (2007). A Taylor rule and the green span era. Economic Quarterly, 93(3), 229-250.

Mishkin, F. S. (2018). Improving the use of discretion in monetary policy. International Finance, 21 (3), 224-238.

Moreira, R.R. (2015). Reviewing Taylor rules for Brazil: Was there a turning-point? Journal of Economics and Political Economy, 2(2), 226-289.

NRB (Nepal Rastra Bank) (2019). Quarterly Economic Bulletin,Mid January, 2019. Nepal Rastra Bank, Baluwatar, Kathmandu, Nepal

Pinga, X. \& Xiongb, L. (2003). Taylor rule in transition economies: A case of China's monetary policy. Statistical Year Book, Baijia Publishing House, 1-18,

Raven, M.O. \& Uhlig. H. (2002).On adjusting the Hodrick-Prescott filter for the frequency of observations. The Review of Economics and Statistics, 84 (2): 371- 376.

Rzhevskyy, A.N. \& Papell, D.H. (2012).Taylor rules and the great inflation.Journal of Macroeconomics, 34, 903-918.

Sghaier, I.M. (2013).Taylor rule and monetary policy in Tunisia. Science and Education Centre of North America, Journal of Finance \& Economics, 1(4), 30-41.

Taylor, J. B. (1993). Discretion versus policy rules in practice. Carnegie Rochester Conference Series on Public Policy,39, 195-214.

Taylor, J. B. (1999). Introduction in monetary policy rules. John B. Taylor, ed. Chicago: Chicago U. Press.

Taylor, J. B. (2011). The cycle of rules and discretion in economic policy. National Affairs, 7 (Spring).

Woodford, M. (2001). The Taylor rule and optimal monetary policy. American Economic Review Papers and Proceedings, 91, 232-237. 